\title{
Massive corals are regularly spaced: pattern in a complex assemblage of corals
}

\author{
R. Endean*, Ann M. Cameron, Helen E. Fox ${ }^{* *}$, Robert Tilbury***, \\ Leanne Gunthorpe ${ }^{* * * *}$
}

Department of Zoology, The University of Queensland, Brisbane 4072, Australia

\begin{abstract}
In November 1994, 955 colonies of scleractinian coral occupied approximately $17 \%$ of a $15 \times 7 \mathrm{~m}$ study area which formed part of an intertidal platform near the reef crest at Heron Island Reef off the NE Australian coast. Of these colonies $468(49 \%)$ were massive corals and $487(51 \%)$ were nonmassives. When 50 colonies belonging to unidentified species of Porites were excluded there remained 418 massive corals belonging to 28 species and 12 genera. Twenty of these species were represented by fewer than the mean number of 13 colonies and $44 \%$ of all colonies of the massive corals present belonged to the species Favites abdita, Montastrea curta and Montastrea annuligera. Although the colonies of massive corals rarely exceeded $50 \mathrm{~cm}$ in diameter, they fell into a wide range of sizes. How ever, the majority of colonies of most species had diameters $>10 \mathrm{~cm}$. Mean annual growth rates varied among species and among colonies of the same species but for most colonies was $\leq 0.5 \mathrm{~cm}$ in diameter $\mathrm{yr}^{-1}$ The total number of colonies of massive corals (excluding colonies of the genus Porites) increased from 382 to 418 from November 1991 to November 1994, with settlement slightly in excess of mortality each year. However, the total area occupied by massive corals remained essentially constant during this period. Most species of massive corals showed no mortality and the low mortality exhibited by each of the remaining species was compensated for by settlement of new colonies. The massive coral colonies were regularly spaced, with a mean centre to centre spacing distance of $27.5 \pm 15 \mathrm{~cm}$ (SD), a mode of $17 \mathrm{~cm}$ and a median of $24 \mathrm{~cm}$. Nearest neighbours were rarely of the same species. We propose that the establishment and maintenance of a structural matrix of massive coral colonies exhibiting the regularly spaced pattern described are based on the release of allelochemicals from these colonies.
\end{abstract}

KEY WORDS: Community structure $\cdot$ Massive corals $\cdot$ Regular spacing pattern

\section{INTRODUCTION}

The occupancy of space on coral reefs by corals has been studied by several workers including Goreau (1959), Lewis (1970), Loya (1972), Connell $(1973,1976)$, Maragos (1974), Stimson (1974), Dana (1976), Bak \& Engel (1979), Sheppard (1979), Bradbury \& Young

·E-mail: acameron@zoology.uq.edu.au

Present addresses:

- Department of Integrative Biology, University of California, Berkeley, California 94720, USA

'.WBM Oceanics Australia, PO Box 604, Market Street, Melbourne 8007, Australia

...Victorian Fisheries Research Institute, Department of Conservation and Environment, PO Box 114, Queenscliff 3225, Australia
(1982, 1983), Done (1982), Wallace \& Bull (1982), Wellington (1982) and Abel et al. (1983). Some attempted to determine the patterns of dispersion exhibited by colonies of particular coral species. Colonies of most species showed an aggregated (clumped) dispersion whilst those of other species were usually dispersed randomly. However, Stimson (1974) found that colonies of Pocillopora meandrina at Hawaii were uniformly dispersed and Abel et al. (1983) found that the Caribbean corals Siderastrea siderea and Agaricia agaricites had abnormally uniform or regular dispersions. Others attempted to categorise coral assemblages by the extent of the contribution to the total coral cover made by particular species. Their attention was focused frequently on relatively shortlived opportunistic species which are often abundantly 
represented. These species often form what are virtually single species stands (zones) in particular habitats and their abundance faciljtates the collection of statistical data. However, it has been pointed out (Endean \& Cameron 1990) that opportunists comprise a minority of the species in complex coral assemblages. Such species-rich assemblages usually occur on platforms or gently sloping regions of consolidated reef substratum that are not subjected to frequent and severe physical disturbances such as heavy wave action or pronounced accumulation or movement of sediments. Numerous long-lived massive coral species, termed persisters, many of which occur at low population density and are considered to be rare, occur in complex assemblages. Indeed, it is axiomatic that the high species richness exhibited by complex assemblages results from a high incidence of rare species. These rare species warrant consideration in any attempt to determine patterns of space occupancy in such assemblages. Their importance stems from virtual constancy in their population sizes and population structures arising, in part, from their marked ability to retain their living space despite disturbances that cause high lurnover rates of the opportunistic species with which they co-exist (Cameron \& Endean 1985, Endean \& Cameron 1985).

Competition for space involving aggressive interactions has been suggested to be a major factor responsible for the spatial patterns exhibited by the various species constituting coral assemblages (see review by Lang \& Chornesky 1990). However, Bradbury \& Young (1982) asserted that the spatial patterns of reef-flat corals at Heron Island Reef, Great Barrier Reef (GBR), were random with respect to species and that aggressive interactions among scleractinians are not a major structuring force in coral communities. This generalisation was criticised by Sheppard (1985) on the basis that Bradbury \& Young (1982) did not use a scale of measurement appropriate to the interactive reach of corals. More importantly in our view, it would appear inevitable that only very small portions of complex coral assemblages were actually sampled by the methodology employed. Because of this, the generalisations made by Bradbury \& Young (1982) may not be applicable to complex coral assemblages. It has been postulated that colonies of persistent species in complex assemblages are regularly spaced (overdispersed) and that toxicity may be a factor fundamental to the production of such ordered patterns of distribution (Endean \& Cameron 1990). Although these hypotheses have not been tested in the field, this line of reasoning has been followed by Licuanan \& Bakus (1993), who suspected a current-modulated pattern in the distribution of corals, and by Maida et al. (1995a, b), who found that a soft coral's presence limited the survival of settled spat of hard corals in a current-related manner.
A complex coral assemblage was observed in a moat-like structure about $5000 \mathrm{~m}^{2}$ in area, seawards of the reef crest on the northern side of Heron Island Reef. The coral assemblage contained many massive coral species (approximately 30 ) as well as several branching and encrusting non-massive species. The massive coral colonies appeared to be regularly spaced. The colonies of non-massive species were scattered and did not form a dense assemblage as they did seawards of the structure. It was decided to examine the distribution of corals, initially massive corals, in this complex coral assemblage over a period of several years. It was anticipated that the study would enable determination of the patterns of dispersion exhibited by massive corals in a complex assemblage, and would provide information on the genesis of such patterns and insight into possible mechanisms underlying such patterns.

\section{MATERIALS AND METHODS}

The corners of a rectangular area, $15 \times 7 \mathrm{~m}$, aligned so that its long axis was approximately parallel with the reef edge, were marked with steel pegs driven into the substratum in December 1983. This study area forms part of an extensive (approximately $500 \mathrm{~m}$ long by approximately $10 \mathrm{~m}$ wide) but shallow, moat-like structure between the reef crest and the reef edge. Initial surveys of the habitat indicated that an area of approximately $105 \mathrm{~m}^{2}$ contained most of the massive coral species present. The structure itself runs parallel with the reef edge and is situated on the northern side of Heron Island Reef $\left(23^{\circ} 26^{\prime} \mathrm{S}, 151^{\circ} 57^{\prime} \mathrm{E}\right)$ to the east of the feature known locally as the 'Blue Pool'. Several such structures occur along the perimeter of the northern side of the reef. The floor of the study area is of dense consolidated reef fabric, for the most part devoid of coral sand and sloping slightly seawards. Areas sparsely covered by low algal turf fill the spaces among coral colonies and among other sessile animals present.

On low water of neap tides, the moat-like structure remains full of water and averages about $0.6 \mathrm{~m}$ in depth but it drains considerably at low water of spring tides, only a few cm of water then remaining on its seaward side. Tidal range in the area is approximately $3 \mathrm{~m}$. Although protected from the direct effects of waves and swell generated by the prevailing southeasterly winds, the study area is exposed to waves and swell generated by winds with a northerly component.

Initially the $15 \times 7 \mathrm{~m}$ area was divided into areas of $1.0 \mathrm{~m}^{2}$ by use of a $1.0 \mathrm{~m}^{2}$ quadrat placed on parallel chains that were $1 \mathrm{~m}$ apart with markers at $1 \mathrm{~m}$ intervals. Every macroscopic sessile animal located in each 
$1.0 \mathrm{~m}^{2}$ of the grid system thereby established was recorded. Corals were identified to species except for colonies of the genera Porites, Acropora, Stylophora and Montipora. Also, some small colonies of massive corals were initially identified to genus only. Identifications were based on the works of Veron \& Pichon (1976, 1980), Veron et al. (1977) and Veron (1986). From November 1984 to November 1990 the position of each massive coral present was determined each year in late November or early December by reference to fixed points in the grid system At the same time, the appearance of new colonies and the demise of colonies that were present the previous year were noted. Also recorded were any changes in the sizes and shapes of colonies since the previous visit. In order to determine the size of each massive colony, 2 measurements (error $= \pm 5 \mathrm{~mm}$ ) were made each year using a metre rule and large dividers. The first measurement was of the greatest horizontal extent of the colony and the second was made normal to the first through the midpoint of the colony, again in the horizontal plane. The average of these yielded the size (average diameter) of the colony.

Relocation of coral colonies by reference to the grid system was time-consuming and problems were encountered in relocating small colonies, particularly when visits coincided with periods of neap tides and/or heavy wave action. It was therefore decided in November 1991 to facilitate the location and measurement of each colony by plotting annually the position and size of each colony to scale on a map of the whole study area. The position of each colony relative to adjacent colonies was determined by measurement (centre to centre and edge to edge) and confirmed by photography. Measurements of the major and minor horizontal axes of each colony (as described above) were used when plotting the respective sizes of colonies on the map. In November 1994 the position and size (to scale) of each non-massive coral colony present were added to the map. This paper deals with data collected from November 1991 to November 1994 inclusive. The number of colonies of each massive species was determined each November (see Table 1). In 1994 a speciesarea curve was plotted and frequency distributions of colonies among species were determined (see Fig. 1). Size frequency groupings based on colony area were established for species of massive coral represented by 6 or more colonies in 1994 (see Fig. 2) and size frequency distributions for species represented by fewer than 6 colonies were also obtained (see Table 2). Areas equivalent to diameters of $5 \mathrm{~cm}$ and multiples thereof were used for the size categories. The maximum size attained by each species of massive coral was also determined (see Table 3). Changes in sizes of colonies between successive annual visits were recorded (see
Tables 4 \& 5). Also, we obtained information on demise of colonies, net settlement between visits and alterations in areas occupied by colonies over this period.

Measurement (accuracy $\pm 5 \mathrm{~mm}$ ) of the minimum distances between neighbouring coral colonies was made in November 1994 for nearest neighbour analysis. For each of the 418 massive coral colonies (excluding those of Porites spp. all of which were too small to be identified in the field and are not included in the results), the distance to its nearest neighbour was measured from colony edge to colony edge, at the nearest points in each case. Coral colonies that settled in 1992,1993 and 1994 were also mapped to scale, and each settler's nearest neighbour (edge to edge) was determined. The mean intraspecific spacing distance was calculated for each massive coral species represented by 6 or more colonies in 1994 (see Table 6). This was done by measuring the distance to the nearest neighbour of the same species from colony centre to colony centre for each colony. In 1994 the number of instances when a colony had a member of the same species as its nearest neighbour was determined for species with 6 or more colonies and the number of instances when a colony had a member of the same genus as its nearest neighbour was determined for Favia, Favites, Goniastrea, Montastrea and Platygyra. The binomial distribution test was used to determine whether the number of colonies that had the same species (or genus) as nearest neighbour was more or less than expected by chance. Interactions between neighbouring colonies observed between November 1991 and November 1994 were recorded.

In order to determine the distribution pattern of the colonies of massive corals, the actual distribution was compared with simulated random distributions. For this process, the centre of each massive colony was used to establish $x-y$ co-ordinates for the colony with reference to the major $(15 \mathrm{~m})$ and minor $(7 \mathrm{~m})$ axes of a $\mathrm{m}^{2}$ grid system superimposed to scale on a map of the colonies present in 1994. Each colony's nearest neighbour within the study area (using centre-to-centre measurements) was determined and the distance separating the members of each nearest neighbour pair recorded (see Fig. 3). The actual mean spacing distance (the mean distance separating the members of each pair of nearest neighbours in the study plot) was then calculated.

Monte Carlo simulations (Sokal \& Rohlf 1995) were used to determine whether the colonies present were randomly distributed, regularly spaced or clumped. For the Monte Carlo program, the computer representation of the map of the $15 \times 7 \mathrm{~m}$ study area was divided into $10 \mathrm{~cm} \times 10 \mathrm{~cm}$ sections. Each coral, regardless of actual size, was treated as a $10 \times 10 \mathrm{~cm}$ square (the median diameter of the actual corals being 
$9.5 \mathrm{~cm}$ ) For the simulations, the same number of massive coral colonies (418 excluding colonies of the genus Porites) as were present in the study area were distributed randomly in the same plot size 1000 times, generating a normal distribution. The mean spacing distance for each simulation was calculated and these were compared with the actual mean spacing distance. If fewer than $5 \%$ of the simulated means were greater than the actual mean, then the coral colonies in the study area were considered to be regularly spaced.

For a second set of simulations, each square metre of the study area was divided into quadrants, yielding a total of 420 quadrants of $0.25 \mathrm{~m}^{2}$. Thirty-three of these carried no massive corals from 1991 to 1994 and no non-massive corals in 1994 and were therefore treated as 'forbidden' for the placement of corals in the random simulations.

\section{RESULTS}

In 1994 a total of 955 scleractinian coral colonies occupied approximately $17 \%$ of the $15 \times 7 \mathrm{~m}$ study area. Of these, $468(49 \%)$ were massive and $487(51 \%)$ were non-massive corals. Other macroscopic sessile animals present were 2 colonies of alcyonarians, 2 colonies of hydrocorals and 10 clams. The 418 colonies of massive corals present in 1994 and listed in Table 1 represent 28 species belonging to 12 genera. Note that colonies identified to genus only are not included in the species totals in Table 1. The species-area curve revealed that the $105 \mathrm{~m}^{2}$ study area contained nearly all the massive coral species in the habitat. Indeed, only an additional 3 species were found in the moat-like structure outside the study area.

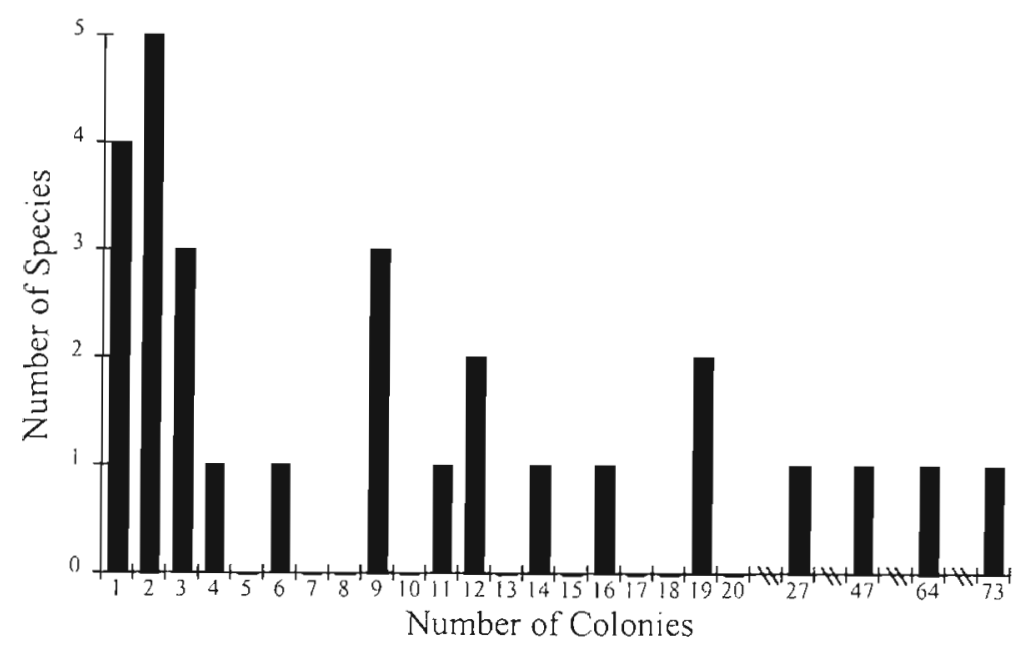

Fig. 1. Frequency distribution of colonies among species of massive coral in the study area in 1994 . The mean number of colonies per species was 13 and the modal number was 2. (Note breaks in $x$-axis)
Many of the massive corals recorded must be regarded as rare. In 1994, 5 species (Cyphastrea serailia, Favia matthai, Favia stelligera, Favites pentagona and Lobophyllia pachysepta) were represented by the modal number of 2 colonies, 4 species (Favia rotumana, Platygyra pini, Platygyra sinensis and Symphyllia recta) were represented by 1 colony and 20 of the 28 species by fewer than the mean number of 13 colonies (Fig. 1 ). Only 3 species were represented by more than 30 colonies. (Note that colonies identified to genus only are not included in Fig. 1.)

Histograms of sizes of the colonies of each species with 6 or more colonies are given in Fig. 2. Sizes of the colonies of species with fewer than 6 colonies are listed in Table 2. It is apparent that colonies of most species were well represented in the 6 to $10 \mathrm{~cm}$ and/or the 11 to $15 \mathrm{~cm}$ diameter categories. Colonies less than $5 \mathrm{~cm}$ in diameter and belonging to Montastrea curta, Montastrea annuligera, Favites abdita and Leptoria phrygia were relatively common, reflecting the extent of recent settlement of colonies of these species. Favia pallida, Platygyra daedalea, F. abdita and M. curta were well represented in the 16 to $20 \mathrm{~cm}$ in diameter category. Colonies of Goniastrea australensis, Goniastrea aspera, Goniastrea retiformis, $P$. daedalea, $M$. curta, M. annuligera, F. pallida, F abdita, Cyphastrea micropthalma and Cyphastrea serailia embraced the greatest range of size categories. The maximum size attained by each species (Table 3 ) may have been constrained by the shallowness of the water at low tide.

Annual changes in the mean size of colonies of each species of massive coral are listed in Table 4 . Colonies of many species showed little change in size during the $3 \mathrm{yr}$ period. Indeed, the mean annual change in diameter for colonies belonging to 15 of the 28 species was $\leq 0.5 \mathrm{~cm} \mathrm{yr}^{-1}$ Some colonies regressed in size. Mean annual growth rates for colonies of the remaining 13 species ranged from 0.5 to $1.0 \mathrm{~cm}$ in diameter. That growth rate varied annually among colonies of a particular species is exemplified by the data for Platygyra daedalea, shown in Table 5. Over the 3 yr period the average growth rate per colony was $\leq 0.5 \mathrm{~cm}$ in diameter $\mathrm{yr}^{-1}$ for 9 of the 25 colonies and between 0.5 and $2.0 \mathrm{~cm}$ in diameter $\mathrm{yr}^{-1}$ for the remainder.

Survivorship of visible settlers for all massive corals was $84 \%(27 / 32)$ for the first year (November 1992 to November 1993) and $72 \%(23 / 32)$ for the 2 yr (November 1992 to November 1994). For Favites abdita the comparable figures are $50 \%$ and $50 \%$ respectively; for Montastrea annuligera they are $100 \%$ and $50 \%$ respectively; for 
Table 1. Genera and species (excluding species of Porites) of massive coral colonies in the $105 \mathrm{~m}^{2}$ plot on Heron Island Reef crest from 1991 to 1994. Number of colonies (N), mortality (M) and settlement (S) in each year for each species are shown. (Where a colony was too small for identification to the species level, the genus only is listed)

\begin{tabular}{|c|c|c|c|c|c|c|c|c|c|c|}
\hline \multirow[t]{2}{*}{ Species } & \multirow{2}{*}{$\begin{array}{c}1991 \\
\mathrm{~N}\end{array}$} & \multicolumn{2}{|c|}{$1991-1992$} & \multirow{2}{*}{$\begin{array}{c}1992 \\
\mathrm{~N}\end{array}$} & \multicolumn{2}{|c|}{$1992-1993$} & \multirow{2}{*}{$\begin{array}{c}1.993 \\
\mathrm{~N}\end{array}$} & \multicolumn{2}{|c|}{$1993-1994$} & \multirow{2}{*}{$\begin{array}{c}1994 \\
\mathrm{~N}\end{array}$} \\
\hline & & M & $\mathrm{S}$ & & $M$ & $\mathrm{~S}$ & & M & $\mathrm{S}$ & \\
\hline \multicolumn{11}{|l|}{ Acanthastrea } \\
\hline A. echinata & 12 & 0 & 0 & 12 & 0 & 0 & 12 & 0 & 0 & 12 \\
\hline \multicolumn{11}{|l|}{ Cyphastrea } \\
\hline C. micropthalma & 4 & 0 & 0 & 4 & 0 & 0 & 4 & 0 & 0 & 4 \\
\hline C. serailia & 2 & 0 & 0 & 2 & 0 & 0 & 2 & 0 & 0 & 2 \\
\hline Cyphastreasp. & 2 & 1 & 0 & 1 & 0 & 0 & 1 & 0 & 0 & 1 \\
\hline \multicolumn{11}{|l|}{ Favia } \\
\hline F. favus & 3 & 0 & 0 & 3 & 0 & 0 & 3 & 0 & 0 & 3 \\
\hline F mathai & 2 & 0 & 0 & 2 & 0 & 0 & 2 & 0 & 0 & 2 \\
\hline F. pallida & 16 & 0 & 0 & 16 & 0 & 0 & 16 & 2 & 0 & 14 \\
\hline F. rotumana & 1 & 0 & 0 & 1 & 0 & 0 & 1 & 0 & 0 & 1 \\
\hline F. stelligera & 2 & 0 & 0 & 2 & 0 & 0 & 2 & 0 & 0 & 2 \\
\hline Favia sp. & 0 & 0 & 0 & 0 & 0 & 0 & 0 & 0 & 4 & 4 \\
\hline \multicolumn{11}{|l|}{ Favites } \\
\hline F. abdita & 65 & 4 & 2 & 63 & 2 & 0 & 61 & 2 & 5 & 64 \\
\hline F. chinensis & 11 & 0 & 0 & 11 & 0 & 0 & 11 & 0 & 0 & 11 \\
\hline F. complanata & 18 & 0 & 2 & 20 & 0 & 0 & 20 & 1 & 0 & 19 \\
\hline F. halicora & 15 & 0 & 2 & 17 & 0 & 2 & 19 & 0 & 0 & 19 \\
\hline F. pentagona & 1 & 0 & 1 & 2 & 0 & 0 & 2 & 0 & 0 & 2 \\
\hline Favites sp. & 17 & 2 & 6 & 21 & 0 & 3 & 24 & 4 & 12 & 32 \\
\hline \multicolumn{11}{|l|}{ Galaxea } \\
\hline G. fascicularis & 0 & 0 & 1 & 1 & 0 & 0 & 1 & 1 & 0 & 0 \\
\hline \multicolumn{11}{|l|}{ Goniastrea } \\
\hline G. aspera & 10 & 1 & 0 & 9 & 0 & 0 & 9 & 0 & 0 & 9 \\
\hline G. australensis & 11 & 1 & 1 & 11 & 2 & 0 & 9 & 0 & 0 & 9 \\
\hline G. favulus & 16 & 5 & 1 & 12 & 0 & 3 & 15 & 3 & 0 & 12 \\
\hline G. retiformis & 15 & 0 & 0 & 15 & 0 & 0 & 15 & 0 & 1 & 16 \\
\hline Goniastrea sp. & 0 & 0 & 2 & 2 & 0 & 1 & 3 & 1 & 1 & 3 \\
\hline \multicolumn{11}{|l|}{ Hydnophora } \\
\hline$H$. exesa & 1 & 0 & 0 & 1 & 0 & 0 & 1 & 1 & 0 & 0 \\
\hline H. microconos & 5 & 0 & 0 & 5 & 0 & 0 & 5 & 0 & 1 & 6 \\
\hline Leptastrea & & & & & & & & & & \\
\hline L. purpurea & 1 & 1 & 0 & 0 & 0 & 0 & 0 & 0 & 0 & 0 \\
\hline Leptoria & & & & & & & & & & \\
\hline L. phrygla & 6 & 0 & 2 & 8 & 0 & 0 & 8 & 0 & 1 & 9 \\
\hline Leptoria sp. & 0 & 0 & 0 & 0 & 0 & 0 & 0 & 0 & 2 & 2 \\
\hline Lobophyllia & & & & & & & & & & \\
\hline L. pachysepta & 5 & 1 & 0 & 4 & 0 & 0 & 4 & 2 & 0 & 2 \\
\hline Montastrea & & & & & & & & & & \\
\hline M. annuligera & 40 & 1 & 2 & 41 & 0 & 1 & 42 & 3 & 8 & 47 \\
\hline M. curta & 64 & 4 & 8 & 68 & 5 & 2 & 65 & 1 & 9 & 73 \\
\hline M. magnistellata & 1 & 1 & 0 & 0 & 0 & 0 & 0 & 0 & 0 & 0 \\
\hline M. valenciennesi & 2 & 0 & 0 & 2 & 0 & 0 & 2 & 0 & 1 & 3 \\
\hline Montastrea sp. & 1 & 1 & 1 & 1 & 1 & 0 & 0 & 0 & 1 & 1 \\
\hline Platygyra & & & & & & & & & & \\
\hline P. daedalea & 26 & 1 & 1 & 26 & 0 & 0 & 26 & 0 & 1 & 27 \\
\hline P. pinl & 1 & 0 & 0 & 1 & 0 & 0 & 1 & 0 & 0 & 1 \\
\hline P. sinensis & 2 & 1 & 0 & 1 & 0 & 0 & 1 & 0 & 0 & 1 \\
\hline Platygyra sp. & 0 & 0 & 0 & 0 & 0 & 1 & 1 & 0 & 0 & 1 \\
\hline Psammocora & & & & & & & & & & \\
\hline P. contigua & 3 & 0 & 0 & 3 & 0 & 0 & 3 & 0 & 0 & 3 \\
\hline Symphyllia & & & & & & & & & & \\
\hline S. recta & 1 & 0 & 0 & 1 & 0 & 0 & 1 & 0 & 0 & 1 \\
\hline Total & 382 & 25 & 32 & 389 & 10 & 13 & 392 & 21 & 47 & 418 \\
\hline Total no of genera & 13 & & & 13 & & & 13 & & & 12 \\
\hline Total no of species & 31 & & & 30 & & & 30 & & & 28 \\
\hline
\end{tabular}



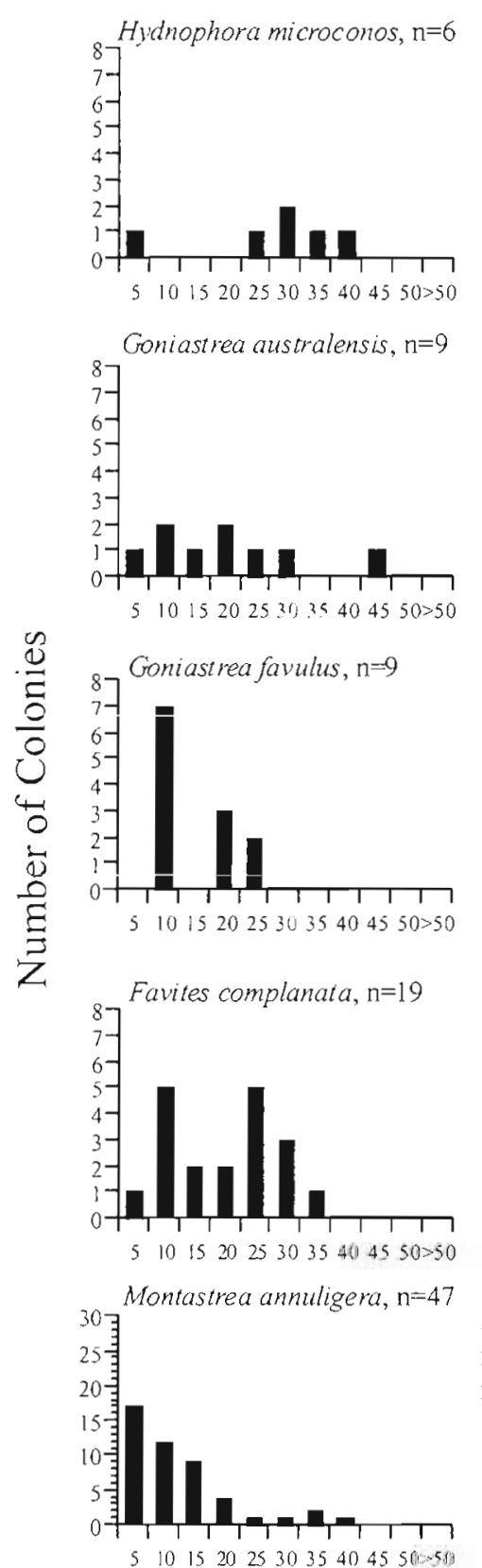
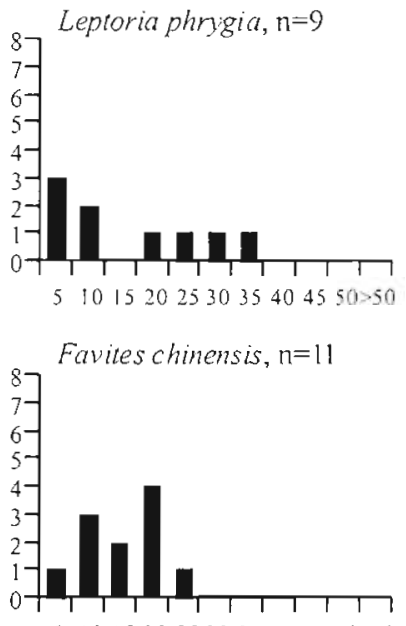

$5101520253035404550>50$
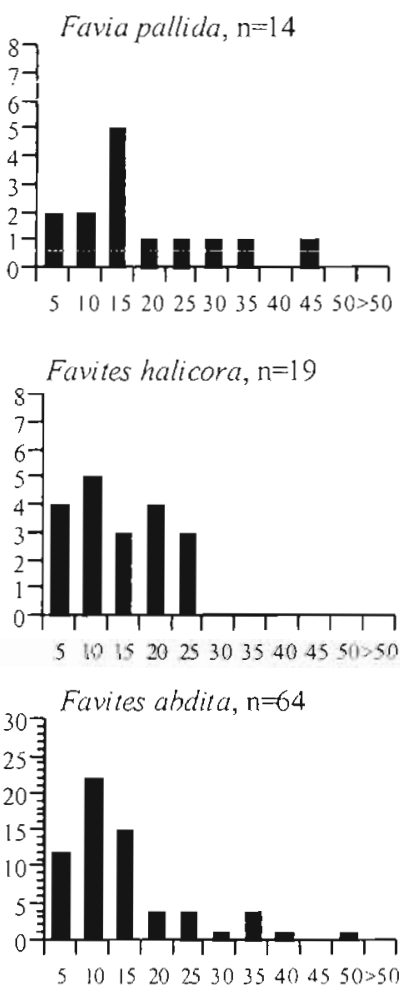

Average Size $(\mathrm{cm})$
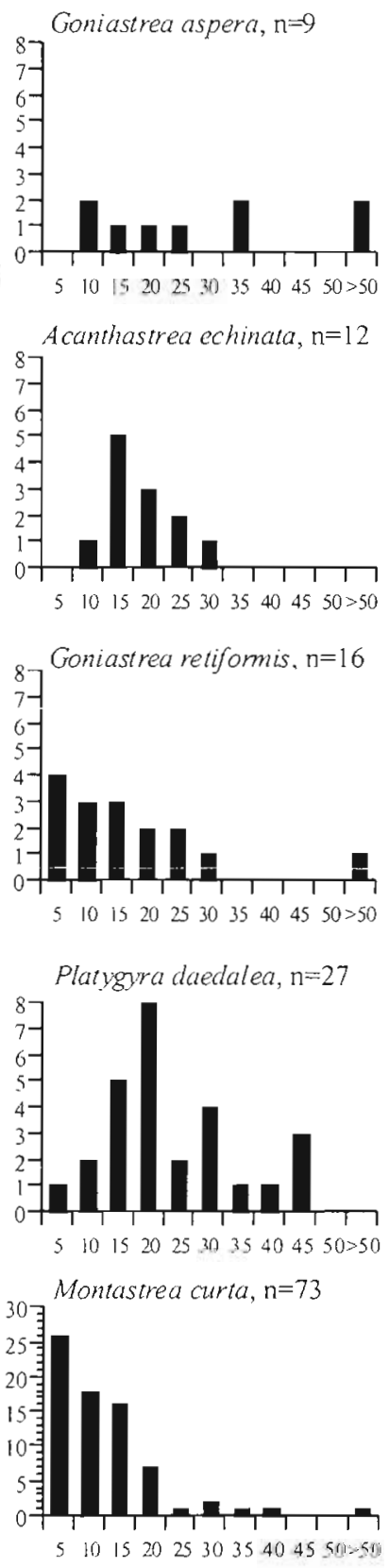

Fig. 2. Histograms showing size distributions of colonies of massive coral species with 6 or more colonies in 1994 . Corals are grouped into $5 \mathrm{~cm}$ size classes equivalent to an average diameter of $<5 \mathrm{~cm}, 6-10 \mathrm{~cm}, 11-15 \mathrm{~cm}$, etc., although the colonies were treated as ellipses in calculation of area

Montastrea curta they are $70 \%$ and $50 \%$ respectively. From November 1991 to November 1994 (Table 1) the total number of colonies of massive species in the study increased from 382 to 418 , with settlement somewhat in excess of mortality each year. However, colonies of most species showed no mortality during this period whilst mortality was compensated for by settlement in others. Indeed, the total area occupied by massive corals during this period remained essentially constant being 10.13 , 10.23, 10.85 and $10.25 \mathrm{~m}^{2}$ between 1991 and 1994. Although more colonies of non-massive species than massive colonies (487:468, respectively) were present in 1994, the area occupied by non-massive colonies was substantially less than that occupied by massive colonies.

The mean centre to centre spacing distance of the 418 massive corals present in 1994 was $27.5 \pm 15 \mathrm{~cm}$ 
Table 2. Size distributions of massive coral species with fewer than 6 colonies in 1994. Increments represent the area equivalent to an average diameter of $<5 \mathrm{~cm}, 6-10 \mathrm{~cm}, 11-15 \mathrm{~cm}$, etc., although the colonies were treated as ellipses in calculation of area

\begin{tabular}{|c|c|c|c|c|c|c|c|c|c|c|c|c|}
\hline \multirow{2}{*}{ Species } & \multirow{2}{*}{$\begin{array}{l}\text { No. of } \\
\text { colonies }\end{array}$} & \multicolumn{11}{|c|}{ Equivalent average diameter $(\mathrm{cm})$} \\
\hline & & $<5$ & $6-10$ & $11-15$ & $16-20$ & $21-25$ & $26-30$ & $31-35$ & $36-40$ & $41-45$ & $46-50$ & $>50$ \\
\hline \multicolumn{13}{|l|}{ Cyphastrea } \\
\hline C. micropthalma & 4 & & 1 & & & & 1 & & & & & 2 \\
\hline C. serailia & 2 & & & & 1 & & & & & & & 1 \\
\hline \multicolumn{13}{|l|}{ Favia } \\
\hline F. favus & 3 & & 2 & 1 & & & & & & & & \\
\hline F. matthai & 2 & & & & & & & & & 2 & & \\
\hline F. rotumana & 1 & & & & 1 & & & & & & & \\
\hline F. stelligera & 2 & & 1 & 1 & & & & & & & & \\
\hline \multicolumn{13}{|l|}{ Favites } \\
\hline F.pentagona & 2 & & & 1 & & & & & 1 & & & \\
\hline \multicolumn{13}{|l|}{ Lobophyllia } \\
\hline L. pachysepta & 2 & 1 & 1 & & & & & & & & & \\
\hline \multicolumn{13}{|l|}{ Montastrea } \\
\hline M. valenciennesi & 3 & 1 & 1 & 1 & & & & & & & & \\
\hline \multicolumn{13}{|l|}{ Platygyra } \\
\hline P. pini & 1 & 1 & & & & & & & & & & \\
\hline P. sinensis & 1 & & 1 & & & & & & & & & \\
\hline \multicolumn{13}{|l|}{ Psammocora } \\
\hline P. contigua & 3 & 2 & & 1 & & & & & & & & \\
\hline \multicolumn{13}{|l|}{ Symphyllia } \\
\hline S. recta & 1 & & & & & & & & 1. & & & \\
\hline Total & 27 & 5 & 7 & 5 & 2 & 0 & 1 & 0 & 2 & 2 & 0 & 3 \\
\hline
\end{tabular}

(SD), with a mode of $17 \mathrm{~cm}$ and a median value of $24 \mathrm{~cm}$ (Fig. 3). The mean spacing distance generated from the 1000 simulations in the Monte Carlo program was $26.5 \mathrm{~cm}$, and $4.2 \%$ of the simulations had mean spacing distances greater than the actual mean, indicating that the corals were regularly spaced. When we excised the $33 \times 0.25 \mathrm{~m}^{2}$ portions of the study area that were devoid of massive species from 1991 to 1994 and in 1994 were also devoid of non-massive corals (an area of $8.25 \mathrm{~m}^{2}$, or $7.86 \%$ of the total area), the mean spacing distance of the 1000 simulations was $26 \mathrm{~cm}$. After the excisions, only $0.7 \%$ of the simulations had mean spacing distances greater than the actual mean, indicating that the massive coral colonies were regularly spaced at the $1 \%$ significance level.

Colonies of different species had mean spacing distances (centre to centre) that varied (Table 6). The mean centre-to-centre spacing distances separating

Table 3. Maximum sizes attained by colonies belonging to species of massive corals represented in the plot in 1994 . Sizes were calculated from measurements of major and minor axes of colonies, which were treated as ellipses. A significant portion of the calculated area of a colony noted as 'patchy' was dead

\begin{tabular}{|c|c|c|c|c|c|}
\hline Species & $\begin{array}{l}\text { Maximum } \\
\text { area }\left(\mathrm{cm}^{2}\right)\end{array}$ & Notes & Species & $\begin{array}{l}\text { Maximum } \\
\text { area }\left(\mathrm{cm}^{2}\right)\end{array}$ & Notes \\
\hline Acanthastrea echinata & 615 & & Goniastrea australensis & 1257 & \\
\hline Cyphastrea micropthalma & 3487 & Patchy & Goniastrea favulus & 325 & \\
\hline Cyphastrea serailia & 2199 & Patchy & Goniastrea retiformis & 2104 & Centre dead \\
\hline Favia favus & 106 & & Hydnophora microconos & 990 & \\
\hline Favia matthat & 1500 & & Leptoria phyrgia & 990 & \\
\hline Favia palluda & 1308 & & Lobophyllia pachysepta & 43 & \\
\hline Favia rotumana & 228 & & Montastrea annuligera & 1103 & \\
\hline Favia stelligera & 99 & & Montastrea curta & 3102 & Patchy \\
\hline Favites abdita & 1593 & & Montastrea valenciennesi & 85 & Patchy \\
\hline Favites chinens1s & 456 & & Platygyra daedalea & 1221 & \\
\hline Favites complanata & 767 & & Platygyra pini & 1 & \\
\hline Favites halicora & 491 & Patchy & Platygyra sinensis & 47 & \\
\hline Favites pentagona & 1014 & Patchy & Psammocora contigua & 118 & \\
\hline Goniastrea aspera & 10249 & Patchy & Symphyllia recta & 1148 & \\
\hline
\end{tabular}


Table 4. Number of colonies (No.), size (average diameter in $\mathrm{cm}$ ), and average yearly change in diameter ( $\Delta$ ) of colonies of massive coral species that persisted from November 1991 to 1994 inclusive, ordered by average annual growth (Avg.) over the

3 years. The minimum and maximum changes in diameter from 1991 to 1994 are indicated by Min. and Max., respectively

\begin{tabular}{|c|c|c|c|c|c|c|c|c|c|c|c|}
\hline \multirow[t]{2}{*}{ Species } & \multirow[t]{2}{*}{ No. } & \multicolumn{7}{|c|}{ Average diameter $(\mathrm{cm})$} & \multirow[t]{2}{*}{ Avg. } & \multirow[t]{2}{*}{ Min. } & \multirow[t]{2}{*}{$\operatorname{Max}$} \\
\hline & & 1991 & 1992 & $\Delta 91-92$ & 1993 & $\Delta 92-93$ & 1994 & $\Delta 93-94$ & & & \\
\hline Platygyra pini & 1 & 9.5 & 3.0 & -6.5 & 1.0 & -2.0 & 1.5 & 0.5 & -2.5 & -8.0 & -8.0 \\
\hline Psammocora contigua & 3 & 15.5 & 15.0 & -0.5 & 150 & 0.0 & 10.0 & -5.0 & -2.0 & -9.5 & 0.5 \\
\hline Cyphastrea micropthalma & 4 & 45.5 & 39.0 & -6.5 & 44.0 & 5.0 & 40.5 & -3.5 & -1.5 & -13.5 & -1.0 \\
\hline Favla tavus & 3 & 10.5 & 10.5 & 0.0 & 10.0 & -0.5 & 8.5 & -1.5 & -0.5 & -4.0 & 0.5 \\
\hline Favites halicora & 16 & 13.0 & 1.3 .5 & 0.5 & 13.5 & 0.0 & 13.0 & -0.5 & 0.0 & -14.5 & 5.5 \\
\hline Montastrea valenciennesi & 3 & 10.0 & 10.0 & 0.0 & 9.0 & -1.0 & 10.0 & 1.0 & 0.0 & -1.0 & 1.0 \\
\hline Montastrea annuligera & 37 & 12.0 & 12.5 & 0.5 & 12.0 & -0.5 & 12.0 & 0.0 & 0.0 & -14.5 & 7.5 \\
\hline Favites chinensis & 11 & 13.0 & 13.5 & 0.5 & 130 & -0.5 & 13.0 & 0.0 & 0.0 & -7.0 & 4.0 \\
\hline Favites abdita & 58 & 13.0 & 13.5 & 0.5 & 14.0 & 0.5 & 13.5 & -0.5 & 0.0 & -8.5 & 7.5 \\
\hline Montastrea curta & 58 & 11.5 & 11.5 & 0.0 & 12.5 & 1.0 & 12.0 & -0.5 & 0.0 & -12.0 & 10.5 \\
\hline Cyphastrea seralia & 2 & 35.0 & 36.0 & 1.0 & 38.5 & 2.5 & 35.5 & -3.0 & 0.0 & -0.5 & 1.5 \\
\hline Goniastrea australensis & 8 & 19.0 & 20.0 & -1.0 & 21.0 & 1.0 & 19.5 & -1.5 & 0.0 & -7.0 & 3.5 \\
\hline Goniastrea favulus & 9 & 12.5 & 12.5 & 0.0 & 13.0 & 0.5 & 14.0 & 1.0 & 0.5 & -1.5 & 3.0 \\
\hline Leptoria phrygia & 6 & 20.0 & 20.5 & 0.5 & 21.5 & 1.0 & 21.0 & -0.5 & 0.5 & -4.0 & 5.0 \\
\hline Favites complanata & 17 & 16.5 & 18.0 & 1.5 & 18.5 & 0.5 & 17.5 & -1.0 & 0.5 & -11.5 & 6.5 \\
\hline Favia stelligera & 2 & 7.5 & 6.5 & -1.0 & 8.0 & 1.5 & 9.0 & 1.0 & 0.5 & 1.0 & 3.0 \\
\hline Favia matthai & 2 & 41.5 & 43.0 & 1.5 & 43.0 & 00 & 43.5 & 0.5 & 0.5 & 1.0 & 3.0 \\
\hline Platygyra daedalea & 25 & 16.0 & 17.0 & 1.0 & 17.0 & 00 & 18.0 & 1.0 & 0.5 & -4.0 & 5.5 \\
\hline Acanthastrea echinata & 12 & 13.5 & 14.5 & 1.0 & 15.5 & 1.0 & 15.5 & 0.0 & 0.5 & -2.0 & 5.5 \\
\hline Favia nallida & 14 & 14.0 & 15.0 & 1.0 & 15.5 & 0.5 & 16.0 & 0.5 & 0.5 & -0.5 & 6.5 \\
\hline Goniastrea aspera & 9 & 34.0 & 36.0 & 2.0 & 36.5 & 0.5 & 37.0 & 0.5 & 1.0 & -5.0 & 7.0 \\
\hline Favia rotumana & 1 & 15.0 & 17.0 & 2.0 & 15.5 & -1.5 & 17.5 & 2.0 & 1.0 & 2.5 & 2.5 \\
\hline Platygyra sinensis & 1 & 5.5 & 6.0 & 0.5 & 7.5 & 1.5 & 8.0 & 0.5 & 1.0 & 2.5 & 2.5 \\
\hline Symphyllia recta & 1 & 36.0 & 39.0 & 3.0 & 38.0 & -1.0 & 38.5 & 0.5 & 1.0 & 2.5 & 2.5 \\
\hline Favites pentagona & 1 & 41.0 & 55.5 & 14.5 & 51.0 & -4.5 & 43.5 & -7.5 & 1.0 & 2.5 & 2.5 \\
\hline Lobophyllia pachysepta & 2 & 3.0 & 6.0 & 3.0 & 5.0 & -1.0 & 5.5 & 0.5 & 1.0 & 0.5 & 5.0 \\
\hline Goniastrea retiformis & $1 j$ & 13.0 & 14.5 & 1.5 & 14.0 & -0.5 & 15.5 & 1.5 & 1.0 & -1.0 & 8.0 \\
\hline Hydnophora microconos & $j$ & 26.0 & 27.5 & 1.5 & 29.0 & 1.5 & 29.5 & 0.5 & 1.0 & 1.5 & 9.0 \\
\hline
\end{tabular}

nearest-neighbour (same species) colonies of Montastrea curta, Favites abdita and Montastrea annuligera, the 3 commonest species, were $61 \pm 38 \mathrm{~cm}$ (SD), $67 \pm$

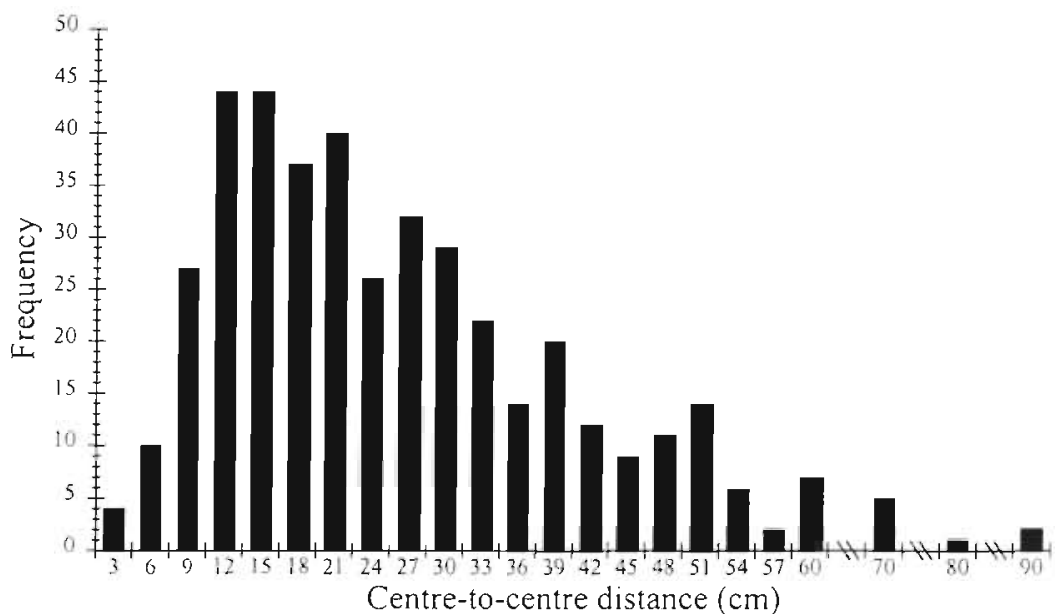

Fig. 3. Frequency distribution of the centre-to-centre spacing distances for the massive coral colonies (excluding Porites spp.) in the study area in 1994, based on the centre coordinates of the nearest neighbour of each coral. Distances are grouped unto intervals of $\leq 3 \mathrm{~cm}, 4-6 \mathrm{~cm}, 7-9 \mathrm{~cm}$, etc
$41 \mathrm{~cm}$ and $78 \pm 43 \mathrm{~cm}$ respectively. The nearest-neighbour records for each of the massive species were also examined for the 15 species with 6 or more colonies in 1994. If $F$. abdita, $M$. curta and $M$. annuligera are excluded, there were only 3 instances in a total of 163 of a nearest neighbour being of the same species. These were 1 recently settled colony of Favites complanata, 2 specimens of Goniastrea retiformis (which may well be 'splinter' colonies from a larger colony) and 2 colonies of Platygyra daedalea which were touching. For $F$ abdita $(n=64)$ there were 8 colonies of which the nearest neighbours were also $F$ abdita and, of these, none was closer than $4 \mathrm{~cm}$, edge to edge. For $M$ curta $(n=73)$ there were 6 colonies the nearest neighbours of which were also $M$. curta and of these, only 1 was closer than $4 \mathrm{~cm}$, edge to edge. For $M$. annuligera $(n=47)$ there were 7 colonies with the same species as nearest 
Table 5. Size (diameter in $\mathrm{cm}$ ) and yearly change in diameter $(\Delta)$ of the 25 individual colonies of Platygyra daedalea that persisted from 1991 to 1994, ordered by average annual growth over the 3 years (Avg.). Sizes were calculated from measurements of major and minor axes of the colonies

\begin{tabular}{|c|c|c|c|c|c|c|c|c|}
\hline Colony & 1991 & 1992 & $\Delta 91-92$ & 1993 & $\Delta 92-93$ & 1994 & $\Delta 93-94$ & Avg \\
\hline 1 & 27 & 28.5 & 1.5 & 22 & -6.5 & 23.25 & 1.25 & -1.3 \\
\hline 2 & 35.5 & 34.75 & -0.75 & 36 & 1.25 & 33.5 & -2.5 & -0.7 \\
\hline 3 & 37.5 & 36.5 & -1 & 40.5 & 4 & 36.5 & -4 & -0.3 \\
\hline 4 & 22 & 22 & 0 & 21 & -1 & 22 & 1 & 0.0 \\
\hline 5 & 12 & 12.5 & 0.5 & 8.5 & -4 & 12.75 & 4.25 & 0.3 \\
\hline 6 & 36.5 & 37 & 0.5 & 37 & 0 & 37.5 & 0.5 & 0.3 \\
\hline 7 & 21 & 21 & 0 & 25.5 & 4.5 & 22 & -3.5 & 0.3 \\
\hline 8 & 8.75 & 10.5 & 1.75 & 9.5 & -1 & 10.25 & 0.75 & 0.5 \\
\hline 9 & 12.5 & 13 & 0.5 & 12.5 & -0.5 & 14 & 1.5 & 0.5 \\
\hline 10 & 12.25 & 13.5 & 1.25 & 13.5 & 0 & 14.25 & 0.75 & 0.7 \\
\hline 11 & 6 & 5.5 & -0.5 & 5.5 & 0 & 8 & 2.5 & 0.7 \\
\hline 12 & 10 & 11.5 & 1.5 & 12 & 0.5 & 12.25 & 0.25 & 0.8 \\
\hline 13 & 15.5 & 18 & 2.5 & 17.5 & -0.5 & 17.75 & 0.25 & 0.8 \\
\hline 14 & 4.5 & 6 & 15 & 6 & 0 & 7 & 1 & 0.8 \\
\hline 15 & 37 & 37 & 0 & 38 & 1 & 39.5 & 1.5 & 0.8 \\
\hline 16 & 2 & 3 & 1 & 3.5 & 0.5 & 4.75 & 1.25 & 0.9 \\
\hline 17 & 8 & 9 & 1 & 10.5 & 1.5 & 10.75 & 0.25 & 0.9 \\
\hline 18 & 12 & 13.5 & 1.5 & 12 & -1.5 & 14.75 & 2.75 & 0.9 \\
\hline 19 & 6.5 & 8 & 1.5 & 8 & 0 & 9.75 & 1.75 & 1.1 \\
\hline 20 & 14.5 & 16 & 1.5 & 16 & 0 & 18 & 2 & 1.2 \\
\hline 21 & 7 & 9.5 & 2.5 & 9.5 & 0 & 10.5 & 1 & 1.2 \\
\hline 22 & 5.5 & 7 & 1.5 & 7.5 & 0.5 & 9.25 & 1.75 & 1.3 \\
\hline 23 & 25 & 28 & 3 & 27 & -1 & 29 & 2 & 1.3 \\
\hline 24 & 4 & 5.75 & 1.75 & 6.5 & 0.75 & 8.25 & 1.75 & 1.4 \\
\hline 25 & 19.5 & 22 & 2.5 & 24.5 & 2.5 & 24.75 & 0.25 & 1.8 \\
\hline Avg & 16.1 & 17.2 & 1.1 & 17.2 & 0.0 & 18.0 & 0.8 & 0.6 \\
\hline
\end{tabular}

chance ( $p<0.05$, binomial test). However, this test yielded random results when applied to nearest-neighbour records for $M$. annuligera and $F$, abdita. Two of the 5 well-represented genera yielded non-random results according to the binomial test. More colonies of species of Favia were nearest neighbours to other colonies of Favia than expected by chance $(\mathrm{p}>$ 0.95). Fewer colonies of species of Montastrea ( $\mathrm{p}<0.05$ ) were nearest neighbours to other colonies of Montastrea than expected by chance.

In 1994 the mean nearest neighbour edge-to-edge distance for all 418 colonies of massive corals was $15.5 \pm 14 \mathrm{~cm}$ (SD), the mode being $5.0 \mathrm{~cm}$ and the median being $10.0 \mathrm{~cm}$. There were 92 instances of edge-to-edge nearest neighbour distances as close as $4 \mathrm{~cm}$ (the maximum interactive reach for any of the species of corals studied). Despite their proximity, there were very few interactions among these adjacent colonies. In only 10 instances over the 3 yr period did deaths of some polyps appear to have stemmed from aggressive interactions. None of these interactions resulted in deaths of entire

Table 6. Number of colonles (No.), mean intraspecific spacing distance (centre to centre) and standard deviation (SD) and median spacing distance for each species with 6 or more individuals occurring in the $105 \mathrm{~m}^{2}$ plot in 1994. All measurements are in $\mathrm{cm}$

\begin{tabular}{|c|c|c|c|c|}
\hline \multirow[t]{2}{*}{ Species } & \multirow[t]{2}{*}{ No. } & \multicolumn{3}{|c|}{ Centre to centre } \\
\hline & & Mean & $\mathrm{SD}$ & Median \\
\hline Montastrea curta & 73 & 61 & 38 & 50 \\
\hline Favites abdita & 64 & 67 & 41 & 55 \\
\hline Montastrea annuligera & 47 & 78 & 43 & 73 \\
\hline Platygyra daedalea & 27 & 114 & 47 & 115 \\
\hline Favites halicora & 19 & 116 & 32 & 127 \\
\hline Goniastrea retiformis & 16 & 123 & 62 & 126 \\
\hline Favites complanata & 19 & 125 & 74 & 116 \\
\hline Goniastrea aspera & 9 & 131 & 79 & 167 \\
\hline Goniastrea favulus & 12 & 134 & 91 & 78 \\
\hline Favia pallida & 14 & 137 & 71 & 131 \\
\hline Goniastrea australensis & 9 & 157 & 82 & 144 \\
\hline Leptoria phrygia & 9 & 164 & 37 & 159 \\
\hline Acanthastrea echinata & 12 & 207 & 7 & 173 \\
\hline Favites chinensis & 11 & 233 & 110 & 244 \\
\hline Hydnophora microconos & 6 & 245 & 71 & 234 \\
\hline
\end{tabular}

neighbours, and none of these was closer than $4 \mathrm{~cm}$, edge to edge. $M$. curta was less likely to have another $M$. curta as its nearest neighbour than expected by colonies and stand-offs involving the previously interacting colonies were occurring by December 1994. It is possible that stand-offs have already occurred in the cases of the other closely adjacent colonies that showed no indication of aggressive interactions.

\section{DISCUSSION}

The species richness of the massive corals in the study area was high. Although fewer colonies of massive species (468) than those of non-massive species (487) were present in 1994, many of the non-massive colonies were small and the massive corals provided more of the coral cover in the area than did non-massives. Even so, total scleractinian coral cover comprised only approximately $17 \%$ of the study area. Other sessile animals scarcely accounted for another $0.5 \%$ The bulk of the cover was provided by epibenthic felt (see Thomassin 1976) on a substratum of consolidated reef rock.

Corals often occupy less than half the area apparently available (Endean 1974, Sheppard 1985). In our study area the total coral cover was less than $20 \%$ of the total area available and the area occupied by mas- 
sive corals was approximately $10 \%$ of the area. It has never been determined whether the space surrounding colonies of persistent corals is indeed available throughout the year for settlement of the larvae of either persistent or opportunistic corals, or, in the longer term, for recruitment of corals.

The total area occupied by massive corals from November 1991 to November 1994 remained essentially constant but there was an increase in the total number of colonies of massive corals, settlement being slightly in excess of mortality each year. It remains to be seen how many of the recent settlers are recruited to the breeding population of each species since mortality among them was substantial. Established colonies of most species showed either no mortality or mortality of $<10 \% \mathrm{yr}^{-1}$ (Table 1 ). Some colonies had attained relatively large sizes (Table 3, Fig. 2) indicating their long-term persistence.

Alhougl colonies rarely exceeded $50 \mathrm{~cm}$ in diameter, a wide range of sizes was found in most massive species. Because of the very low growth rates $(\leq 0.5 \mathrm{~cm}$ in diameter $\mathrm{yr}^{-1}$ ) of most colonies and because the majority of colonies of most species had diameters greater than $10 \mathrm{~cm}$, their ages appear to span decades. Thus physical disturbance capable of killing established colonies has not been responsible for the low cover of massive corals observed in the study area since 1983. Certainly no marked physical disturbances such as severe cyclones that might cause large scale mortality of massive corals have been recorded at Heron Island Reef since 1983.

The difficulties of relating size of coral to age are well known (see Hughes \& Jackson 1980. Hughes \& Connell 1987) and the actual ages of the colonies in the study area could not be determined. Although some colonies showed mean annual increments consistent with published radial growth rates of approximately $5 \mathrm{~mm} \mathrm{yr}^{-1}$ (1 cm in diameter $\mathrm{yr}^{-1}$ ) for species of Platygyra and Goniastrea (Babcock 1985), many colonies did not show detectable changes in size within the limits of experimental error and some colonies had definitely regressed in size. Also, colonies of some species (e.g. Goniastrea favulus) had apparently reached maximum size, as larger specimens were not observed elsewhere on the Heron Island Reef flat. Intrinsic factors may have been responsible for the slowing of growth as maximum size was approached (see Soong 1993). Then too, the growth rates of massive corals present may have been affected adversely by the physical as well as biological conditions prevailing in the study area. The tops of several of the colonies, particularly those on the shallower lagoon side of the study area, were dead, indicating that the potential for growth of these colonies in the vertical plane was restricted. In this regard, the shallowness of the water at low tide would prevent branching corals from competing with massive corals by overtopping. However, some colonies of massive corals in the deeper reef edge side of the study area remained covered by water during most low tides yet showed very low growth rates. The possibility that biotic factors were involved in slowing growth and limiting the sizes attained by some colonies in the study area should be considered. During the study period instances of partial or complete mortality of established colonies of most species of massive corals were few.

Sheppard (1985) accounted for some of the vacant space in the vicinity of corals in terms of their interactive reach. For approximately 50 species this ranged from 0.4 to $4.0 \mathrm{~cm}$. Clearly interactive reach is effective in maintaining apparently unoccupiable space in the immediate vicinity (within $4 \mathrm{~cm}$ ) of established colonies. It must thus be important in determining the fate of some settling propagules but its importance to established colonies is not so clear (see e.g. Bak et al 1982). In the complex assemblage at Heron Island Reef, the incidence of obvious interactions among coral colonies was extremely low. Moreover, the radius of the apparent zone of vacant space surrounding each colony was usually much greater than could be accounted for by interactive reach. The mean edge-toedge spacing distance between adjacent coral colonies was $15.5 \pm 14 \mathrm{~cm}$ (SD), with a median of $10 \mathrm{~cm}$ and a mode of $5 \mathrm{~cm}$. If coral colonies grew closer than approximately $4 \mathrm{~cm}$ (edge to edge), destructive interference (overgrowth, partial destruction of polyps) was rarely apparent, and stand-offs appeared to have occurred when colonies were so close. In the few instances when colonies of the same species were nearest neighbours, only colonies of Platygyra daedalea appeared capable of abutting on one another without fusion. Perhaps different morphs of this species are involved (see Miller 1994).

Because instances of direct interference between coral colonies were few it is possible that competitive interactions were expressed in a more subtle fashion. For example, growth suppression in some coral colonies may have been caused by allelochemicals exuded from adjacent colonies. That one scleractinian species found at Heron Island Reef has the potential to release toxic exudates adversely affecting other scleractinians was demonstrated by Gunthorpe \& Cameron (1990).

The low population densities of most species of massive coral should be emphasised. Approximately one-third of the species in the $15 \times 7 \mathrm{~m}$ study area were represented by only 1 or 2 colonies and approximately two-thirds of the species were represented by fewer than the mean of 13 colonies. Only 3 species were represented by more than 30 colonies. No meaningful 
description of this complex coral community could be made on the basis of the numerical dominance of colonies of a particular species or on the basis of extent of cover by colonies of a particular species. No small group of species characterises this assemblage. It is a diverse assemblage comprised of a large number of persistent massive species, most of which are rare, and a number of branching species, some of which have a high turnover and are considered to be opportunists. Overall, the massive coral colonies are not randomly distributed. Nor are they clumped. On the contrary, massive coral colonies in the complex assemblage studied were regularly spaced.

The mean intraspecific spacing distances of nearest neighbours (centre to centre) for the 15 species with 6 or more colonies varied. For the 4 commonest species the intraspecific spacing distance is inversely related to relative abundance, but this relationship is not so clear for the other 11 species. Although the mean intraspecific spacing distance calculations made involved $83 \%$ of the total number of colonies of massive species present, they pertain to only 15 of the 28 species present in 1994, and we are faced with the problem that almost half the species of this rich assemblage are too rare to be included in the analyses.

We have shown that in a complex coral community massive coral colonies are regularly spaced. Also, we have noted that there appears to be a zone (greater than that of interactive reach) around each massive coral colony where recruitment of new coral colonies is inhibited. If the apparent zones of inhibition surrounding existing coral colonies overlap, no opportunities may be presented for effective settlement of coral larvae. Such settlement could occur only when one or more existing colonies in the complex assemblage are killed, a rare occurrence in the case of persistent massive corals. However, space in complex assemblages made available by the deaths of massive corals or space unsuited because of unfavourable physical features for long-term occupancy by corals may be occupied temporarily by opportunists such as Pocillopora damicornis, further adding to the complexity of the system.

In the complex community studied, the persistence of individuals of massive corals, their low mortality, low rates of recruitment and low rates of growth result in a constancy of colony numbers and a constancy of population size frequencies not previously documented in coral reef biology. We are currently examining the possibility that established massive corals constitute a structural matrix from which chemical compounds are released. We propose that the compounds are essentially toxins that effectively produce a zone of chemical inhibition around each established coral colony that restricts the settlement of new colonies within the zone and slows the growth of the polyps of neighbouring colonies, thereby limiting the extent of their intrusion into the zone. All this would result in the colonies of massive corals present in the complex assemblage studied being regularly spaced.

Acknowledgements. We thank J. K. Hendrikz, H. I. McCallum, P. Gofton and D. MCPhee for help with statistical analyses, K. Aberdeen for the Monte Carlo program used and V. Bylund, L. deVantier, W. Ellis, R. Fearon, J. Keys, L. Llewellyn, K. Miller, S. Monks, A. Poulsen and K. Watson for assistance in the field. We thank the staff at the Heron lsland Station for use of the facilities there. The University of Queensland provided funds for this research and the Fulbright Foundation supported H.E.F. as a Fulbright Scholar for 1 yr.

\section{LITERATURE CITED}

Abel DJ, Williams WT, Sammarco PW, Bunt JS (1983) A new numerical model for coral distribution. Mar Ecol Prog Ser 12:257-265

Babcock RC (1985) Growth and mortality in juvenile corals (Goniastrea, Platygyra and Acropora): the first year Proc 5th Int Coral Reef Congr 4:355-360

Bak RPM, Engel MS (1979) Distribution, abundance and survival of juvenile hermatypic corals (Scleractinia), and the importance of life history strategies in the parent coral community. Mar Biol 54:341-352

Bak RPM, Termaat RM, Dekker R (1982) Complexity of coral interactions: influence of tume, location of interaction and epifauna. Mar Biol 69:215-222

Bradbury RH, Young PC (1982) The race and the swift revisIted, or is aggression between corals important? Proc 4 th Int Coral Reef Symp 2:351-356

Bradbury RH, Young PC (1983) Coral interactions and community structure: an analysis of spatial pattern. Mar Ecol Prog Ser 11:265-271

Cameron AM, Endean R (1985) Do long-lived species structure coral reef ecosystems? Proc 5th Int Coral Reef Congr 6:211-215

Connell JH (1973) Population ecology of reef building corals In: Jones OA, Endean R (eds) Biology and geology of coral reefs, Vol ll, Biology 1 Academic Press, New York, p 205-244

Connell JH (1976) Competitive interactions and the species diversity of corals. In: Mackie GO (ed) Coelenterate ecology and behaviour. Plenum Press, New York, p 51-58

Dana TF (1976) Reef-coral dispersion patterns and environmental variables on a Caribbean coral reef. Bull Mar Sci 26:1-13

Done TJ (1982) Patterns in the distribution of coral communities across the central Great Barrier Reef. Coral Reefs 1: $95-107$

Endean R (1974) Acanthaster planci on the Great Barrer Reef. Proc 2nd Int Symp Coral Reef 1:563-576

Endean R, Cameron AM (1985) Ecocatastrophe on the Greal Barrier Reef. Proc 5th Int Coral Reef Congr 5:309-314

Endean R. Cameron AM (1990) Trends and new perspectives in coral reef ecology. In: Dubinsky $Z$ (ed) Ecosystems of the world, Vol 25, Coral reefs. Elsevier, Amsterdam, p $469-492$

Goreau TF (1959) The ecology of Jamaican cora] reefs l. Species composition and zonation. Ecology 40:67-90

Gunthorpe L, Cameron AM (1990) Toxic exudate from the hard coral Goniopora tenuidens. Toxicon 28:1347-1350 
Hughes TP, Connell JH (1987) Population dynamics based on size or age? A reef-coral analysis. Am Nat 129:818-829

Hughes TP, Jackson JBC (1980) Do corals lie about their age? Some demographic consequences of partial mortality, fission and fusion. Science 209:713-715

Lang JC, Chornesky EA (1990) Competition between reef corals - a review of mechanisms and effects. In: Dubinsky $Z$ (ed) Ecosystems of the world, Vol 25, Coral reefs. Elsevier, Amsterdam, p 209-252

Lewis JB (1970) Spatial distribution and pattern of some Atlantic reef corals. Nature 227:1158-1159

Licuanan WY, Bakus GJ (1993) Coral spatial distributions: the ghost of competition past roused? Proc 7 th Int Coral Reef Symp 1:545-549

Loya Y 11972) Community structure and species diversity of hermatypic corals at Eilat, Red Sea. Mar Biol 13: $100-123$

Maida M, Sammarco PW, Coll JC (1995a) Preliminary evidence for directional allelopathic effects of the soft coral Sinularia flexibilis (Alcyonacea: Octocorallia) on scleractinian coral recruitment. Bull Mar Scl 56:303-311

Maida M, Sammarco PW, Coll JC (1995b) E.ffects of soft corals on scleractinian coral recruitment 1 . directional dllelopatily and inhibition of settlement. Mar Ecol Prog Ser 121: $191-202$

Maragos JE (1974) Coral community on a seaward reef slope, Fanning Island. Pacif Sci 28:257-273

Miller KJ (1994) Morphological variation in the coral genus Platygyra: environmental influences and taxonomic implications. Mar Ecol Prog Ser 1 10:19-28

Sheppard CRC (1979) Interspecific aggression between reef corals with reference to their distribution. Mar Ecol Prog Ser 1:237-247

This article was submitted to the editor
Sheppard CRC (1985) Unoccupied substrate in the central Great Barrier Reef: role of coral interactions. Mar Ecol Prog Ser 25:259-268

Sokal RR, Rohlf FJ (1995) Biometry: the principles and practices of statistics in biological research, 3rd edn. WH Freeman and Company, San Francisco

Soong K (1993) Colony size as a species character in massive reef corals. Coral Reefs 12:77-83

Strmson J (1974) An analysis of the pattern of dispersion of the hermatypic coral Pocillopora meandrina var nobulis Verrill. Ecology 55:445-449

Thomassin BA (1976) The feeding behaviour of the felt-, sponge-, and coral-feeding sea stars, mainly Culcita schmideliana. Helgol Wiss Meeresunters 28:51-65

Veron JEN (1986) Corals of Australia and the Indo-Pacific. Angus and Robertson, Sydney

Veron JEN, Pichon M (1976) Scleractinia of Eastern Australia Part I. Families Thamnasteriidae, Astrocoeniidae, Pocilloporidae. Aust Inst Mar Sci Monogr Ser 1

Veron JEN, Pichon M (1980) Scleractinia of Eastern Australia Part III. Families Agariciidae, Siderastreidae, Fungiidae, Oculinidae, Merulinidae, Mussidae, Pectiniidae, Caryophyỉiidae. Dendrophyiliıdae. Aust Inst Mar Sci Monogr Ser 4

Veron JEN, Pichon M, Wi.js.man-Best M (1977) Scleractinia of Eastern Australia Part II. Families Faviidae, Trachyphylliidae. Aust Inst Mar Sci Monogr Ser 3

Wallace CC, Bull GD (1982) Patterns of juvenie coral recruitment on a reef front during a spring-summer spawning period. Proc 4th Int Coral Reef Symp 2:345-350

Wellington GM (1982) Depth zonation of corals in the Gulf of Panama: control and facilitation by resident reef fishes Ecol Monogr 52:223-241

Manuscript first recelved: June 3,1996

Revised version accepted: March 18, 1997 